\title{
Review \\ The Use of Ozone as an Eco-Friendly Strategy against Microbial Biofilm in Dairy Manufacturing Plants: A Review
}

\author{
Felice Panebianco, Selene Rubiola (D) and Pierluigi Aldo Di Ciccio *(D)
}

\author{
Department of Veterinary Sciences, University of Turin, Largo Braccini 2, Grugliasco, 10095 Torino, Italy; \\ felice.panebianco@unito.it (F.P.); selene.rubiola@unito.it (S.R.) \\ * Correspondence: pierluigialdo.diciccio@unito.it
}

Citation: Panebianco, F.; Rubiola, S.; Di Ciccio, P.A. The Use of Ozone as an Eco-Friendly Strategy against Microbial Biofilm in Dairy Manufacturing Plants: A Review. Microorganisms 2022, 10, 162. https: / /doi.org/10.3390/ microorganisms10010162

Academic Editors: Alida Musatti and Laura Higueras

Received: 10 December 2021

Accepted: 10 January 2022

Published: 13 January 2022

Publisher's Note: MDPI stays neutral with regard to jurisdictional claims in published maps and institutional affiliations.

Copyright: (C) 2022 by the authors. Licensee MDPI, Basel, Switzerland. This article is an open access article distributed under the terms and conditions of the Creative Commons Attribution (CC BY) license (https:// creativecommons.org/licenses/by/ $4.0 /)$.

\begin{abstract}
Managing spoilage and pathogenic bacteria contaminations represents a major challenge for the food industry, especially for the dairy sector. Biofilms formed by these microorganisms in food processing environment continue to pose concerns to food manufacturers as they may impact both the safety and quality of processed foods. Bacteria inside biofilm can survive in harsh environmental conditions and represent a source of repeated food contamination in dairy manufacturing plants. Among the novel approaches proposed to control biofilm in food processing plants, the ozone treatment, in aqueous or gaseous form, may represent one of the most promising techniques due to its antimicrobial action and low environmental impact. The antimicrobial effectiveness of ozone has been well documented on a wide variety of microorganisms in planktonic forms, whereas little data on the efficacy of ozone treatment against microbial biofilms are available. In addition, ozone is recognized as an eco-friendly technology since it does not leave harmful residuals in food products or on contact surfaces. Thus, this review intends to present an overview of the current state of knowledge on the possible use of ozone as an antimicrobial agent against the most common spoilage and pathogenic microorganisms, usually organized in biofilm, in dairy manufacturing plants.
\end{abstract}

Keywords: microbial biofilm; dairy plants; dairy products; ozone; innovative technologies; foodborne pathogens; spoilage bacteria; food quality; food safety

\section{Introduction}

The management of microbial contamination in the food chain is the main goal of the modern food industry. In particular, the control of contamination by spoilage bacteria, such as Pseudomonas spp., as well as pathogenic bacteria, such as Listeria monocytogenes, Salmonella spp., etc., represents a big challenge for the dairy industry. If environmental conditions are suitable, these spoilage and pathogenic bacteria can quickly form biofilm and persist in dairy processing plants. Microorganisms in a biofilm state, indeed, can survive in harsh environmental conditions [1-3]. In this context, the presence of biofilms that include spoilage and pathogenic bacteria constitutes a source of repeated food contamination with consequent issues related to the shelf life and safety of dairy products [4]. Microbial biofilms can be found wherever moisture and sufficient nutrients are available. In this regard, food processing plants, especially dairy plants, become an ideal environment for biofilm formation by several microorganisms [5]. It is well known that the presence and control of microbial biofilm represent a big issue for the whole dairy food chain, from milk collection to waste management [6]. Maintaining adequate hygienic conditions is crucial for preventing biofilm formation by pathogenic and/or spoilage microorganisms in food environments. Currently, biofilm development in food processing facilities, including dairy plants, is controlled by using common biocides, such as quaternary ammonium compounds, alcohols, aldehydes, peracetic acids or chlorine compounds, and by following daily accurate sanitation procedures. Anyway, bacteria inside biofilm are much more resistant to antimicrobials. The biofilm, in fact, can protect bacteria against the action of 
cleaning agents and disinfectants [4,7]. However, the application of biocide compounds has some drawbacks, including detrimental impacts on the environment and deleterious consequences for human health [8]. In addition, the use or misuse of biocides could presumably act as selection pressures for increased microbial resistance to antimicrobial compounds, and the sanitizers may lose effectiveness over time. This phenomenon, known as antimicrobial cross-resistance [3,9-12], is considered as one of the most relevant risks to public health worldwide [13].

As a result, the interest in additional or alternative compounds has increased in the last few years. Considering the concerns for the microbial contamination and biofilms formed by spoilage or pathogenic bacteria and the high cost of managing these issues in processing plants, the identification of novel strategies represents one of the most critical challenges that the modern food industry will face in the following years. Therefore, several innovative strategies, such as the use of antimicrobial peptides, bacteriophages, bacteriocins, essential oils, hydrostatic pressure, cold plasma, hot steam, and ultrasonication, have been proposed to prevent and control microbial contamination in food environments [1,14-17]. Among these new methods, ozone $\left(\mathrm{O}_{3}\right)$ seems to be a promising tool to prevent microbial contamination by spoilage or pathogenic bacteria. Ozone, in fact, is characterized by high antimicrobial activity and it is recognized as an eco-friendly technology due to its low environmental impact [8,18-22]. In addition, ozone breaks down into oxygen without leaving dangerous residues on food or food-contact surfaces [20,23,24]. Ozone, when used in a gaseous state, can reach niches and other "dead zones" within food processing environments, where microorganisms can persist more easily after conventional cleaning and disinfecting programs [25,26]. Recently, several studies have highlighted that ozone may effectively control microbial contamination and biofilms in the food industry and can be a valid alternative or an additional tool to conventional strategies based on chemical disinfection $[19,23,27-30]$. Hence, this review intends to provide an overview of the current state of knowledge on the possible use of ozone as an antimicrobial agent against the most common spoilage and pathogenic microorganisms, usually organized in biofilm, in dairy manufacturing plants.

\section{Biofilm Occurrence in the Dairy Industry}

In a recent review [6], the role of microbial biofilm in the dairy industry has been described extensively. It is well known that bacteria can form biofilm at each point of the production process and in different parts of the processing equipment, including tanks, silos, pipelines, tubes, membranes, walls, plate heat exchangers, etc. [31]. Biofilms of spoilage microorganisms or pathogenic bacteria in milk processing plants are deemed as a major problem. Teh et al. [32], in fact, demonstrated that biofilms formed by Bacillus licheniformis, Streptococcus uberis, Pseudomonas fluorescens, Pseudomonas fragi and Serratia liquefaciens on the internal surfaces of raw milk tankers may be sources of proteolytic enzymes. The persistence of these microorganisms, especially Pseudomonas spp., and the production of thermostable proteases can lead to the potential spoilage of milk during the subsequent steps in the dairy supply chain [32,33]. A review addressed in detail the role of bacterial biofilms as an emerging source of spoilage enzymes in the dairy environment, emphasizing the importance of biofilm control in dairy plants to improve product quality and avoid economic losses [34]. Additionally, the presence of biofilms of pathogenic bacteria in milking equipment and milk storage tanks may increase the risk of causing foodborne illness. In regard to this, Latorre et al. [35] demonstrated that biofilms in milking equipment on a dairy farm can represent a source of Listeria monocytogenes contamination in bulk tank milk. Another study showed that biofilm formed by Staphylococcus aureus could be an important contamination source for bulk tank milk [36]. Consolidated biofilms were identified as a cause of the persistent contamination of Campylobacter jejuni in raw milk [37]. Bacterial biofilms can be found also in membranes used for filtration of milk and other fluids in dairy industries, such as whey and water. This topic has been addressed in detail in a review produced by Anand et al. [38], highlighting how in biofilms 
detected in this equipment both spoilage and pathogenic microorganisms could coexist for a long time. In the biofilm formed on microfiltration and reverse osmosis membranes, seventeen different bacterial groups were detected, with Proteobacteria identified as the major represented group [39]. Recently, a study carried out by Chamberland et al. [40] clarified the composition of biofilms found in spiral-wound membranes, commonly used in milk processing industries. Proteobacteria, Firmicutes, and Actinobacteria were the three major represented phyla. Proteobacteria were dominant (relative abundances of 63.62 and $62.68 \%$ ) for membranes used for ultrafiltration of pasteurized milk. In those samples, the highest proportion of Actinobacteria was also detected. Methylobacterium spp. was the most abundant genus, while the prevalent Bacilli genera were Streptococcus spp., Enterococcus spp., and Lactococcus spp. Acinetobacter spp., Cronobacter spp., and Klebsiella spp., instead, were the dominant $\gamma$-Proteobacteria found. Regarding the spiral-wound membranes used for cheese whey, whey permeate, and water blend filtration, Firmicutes was the most represented phylum, due to the presence of a high Bacilli class ratio. Biofilm formation in heat exchangers may have strong negative effects, as reported by Marchand et al. [31]. The flow of milk in the exchangers, in fact, results in a denaturation of proteins with consequent fouling. This can accelerate the adhesion of microorganisms on the exchangers surface and lead to the formation of biofilms [41]. Sharma and Anand [42] evaluated the biofilms of pasteurization lines in commercial and experimental dairy plants and found the Bacillus genus to be predominant in both cases. The same authors emphasized that the assessment of biofilms and the development of efficient sanitization protocols should be part of the HACCP plan in dairy industries. Biofilms can be present also in filler nozzles. In this regard, Mugadza et al. demonstrated that biofilms formed by Bacillus cereus in filler nozzles could be the main cause of extended-shelf-life milk contamination [43]. Weber et al. [44] analyzed the biofilms of milking machines of two dairy farms. The outcomes demonstrated high bacterial diversity, including the phyla Actinobacteria, Bacteroidetes, Firmicutes, and Proteobacteria. Biofilms were also detected on several materials, such as stainless steel and plastic, which are used in milking machines and in processing plants.

Microbial biofilms are commonly found in cheese processing environments. In a work conducted by Lee et al. [45], persistent biofilm forming L. monocytogenes strains were isolated at different points in Brazilian cheese processing plants, including the cooling chamber $(n=16)$, floor of pasteurization room $(n=8)$, floor of cooling chamber $(n=32)$, plastic crates $(n=8)$, platform of cooling chamber $(n=7)$, surfaces of worker's gloves $(n=3)$, and brine $(n=5)$. Persistent L. monocytogenes strains, organized in biofilm, were detected in Gorgonzola cheese processing plants located in Italy [46]. Bacterial biofilms are commonly detected on wooden shelves used during the ripening process of several traditional cheeses. In this case, biofilms may also have a positive impact on the final products, as these can be composed by the desired dairy lactic acid bacteria. Lactic acid bacteria, in fact, can inhibit the growth of undesirable microorganisms through the production of several antimicrobial compounds [47,48]. A study conducted by Didienne et al. [49] characterized biofilms of 'gerles' (wooden vats used in PDO Salers cheese making) and identified their role in milk inoculation and in preventing pathogen development. Biofilms were mainly composed of different lactic acid bacteria, Gram-positive catalase positive bacteria and yeast, while they were not contaminated by Salmonella, L. monocytogenes or S. aureus. These authors showed that wooden surfaces used during the production of these traditional cheeses are a safe system and a microbiologically active tool. Another study demonstrated the positive influence of spontaneous biofilms grown on wooden surfaces on the microbiological, chemical, physical, and sensory characteristics of PDO Vastedda della valle del Belìce cheese [50]. 


\section{Ozone}

Despite the regular application of cleaning and disinfection plans, bacterial biofilms containing spoilage or pathogenic bacteria are commonly found in dairy manufacturing plants. The biofilm, in fact, protects bacteria against the effects of cleaning agents and disinfectants. Among the innovative strategies, ozone, in its aqueous or gaseous form, is considered to be a promising eco-friendly technology and may be applied as an additional tool to control microbial biofilm in dairy processing environments.

\subsection{Chemical, Physical Properties, and Antimicrobial Action}

Ozone is a blue gas with a characteristic pungent smell and it is known as the second most powerful oxidizing agent after fluorine. An ozone molecule is formed by three oxygen atoms with a central nucleus attached to two equidistant atoms. This structure and the arrangement of the unpaired electrons are responsible for its strong reactivity $[27,28]$. The high oxidative potential, the instability and the reactivity determine the antimicrobial activity of ozone. Ozone exerts its action on microorganisms attacking the constituents of cell membranes, cell envelopes, cytoplasm, spore coats, and virus capsids [29]. Two principal mechanisms of microorganisms' destruction by ozone were identified [29]. The first one is related to the oxidative action of ozone on the sulfhydryl groups and amino acids of enzymes, peptides and proteins that lead to the formation of shorter peptides, while the second mechanism involves the ability of ozone to oxidize polyunsaturated fatty acids in peroxides. In this regard, the double bonds of unsaturated lipids of the cell envelope are especially sensitive to ozone action. The degradation of these components causes the destruction of cells and the loss of intracellular contents [27]. After the breakdown of the bacterial cell wall, the polyunsaturated fatty acids that constituted the phospholipids of the cytoplasmic membrane undergo a peroxidation process due to ozone action. The peroxides resulting from this process cause substantial changes to the physical properties of the cell membranes, with subsequent depolarization and inhibition of enzymes and transport proteins [29]. As mentioned above, the high oxidative potential of ozone can also result in the degradation of amino acids, proteins, and nucleic acids. This mechanism comes into action when the first one (destruction of the membrane) fails to cause the cell death, but the destruction of membrane barriers is deemed as the main factor leading to nucleic acid damages and cell death [29,51].

\subsection{Generation}

Generation of ozone is relatively easy and is performed "in situ", since ozone is characterized by high instability and its storage is difficult [20,52]. Several generation methods exist for the practical applications of ozone, even if the electrical and the photochemical (UV) methods are the most used [29]. With the electric corona discharge method, for example, oxygen molecules pass through an electrical field between two electrodes, and they split generating radicals that produce ozone by combining with the oxygen molecule. Ozone may be generated also by ultraviolet radiation, with the passage of oxygen gas molecules in a short-wave UV light high-energy [52]. Other generation techniques include thermal, chemical, electrolytic, and chemonuclear methods [19].

\subsection{Parameters That Affect the Antimicrobial Performances}

The efficiency of ozone is influenced by several factors, among which the $\mathrm{pH}$ is one of the most important. It has been demonstrated that ozone is more stable at low $\mathrm{pH}$. Ozone is completely dissolved at $\mathrm{pH}$ values lower than 7 , while an increase in $\mathrm{pH}$ causes spontaneous ozone decomposition, which leads to the production of highly reactive free radicals. At $\mathrm{pH} \mathrm{8,} \mathrm{almost} \mathrm{half} \mathrm{of} \mathrm{the} \mathrm{introduced} \mathrm{ozone} \mathrm{is} \mathrm{decomposed}$ to various intermediate forms and to oxygen [29]. The generated radicals increase the efficiency $[19,53]$. Temperature can also affect the solubility and the effectiveness of ozone. Ozone, indeed, becomes less stable and soluble when the temperature increases, while also becoming more reactive [19]. Relative humidity (RH) represents another important 
parameter for the antimicrobial efficiency of ozone. Pascual et al. [20] reported that the bactericidal effect of gaseous ozone reaches an optimum at RH of 90-95\%, while no effect was observed at below 50\%. Another aspect to consider is represented by the presence of organic matter, which is known to decrease the effectiveness of ozone, pointing out the importance of avoiding the presence of residual organic materials in the environment for the application of this technology $[19,26,53]$.

\subsection{Aqueous or Gaseous Form?}

Ozone may be applied in dairy industries in aqueous and/or in gaseous form. The form to be used must be carefully chosen according to the needs and structural characteristics of processing plants. Generally, ozone in aqueous solutions seems more effective on food-related microorganisms than ozone in the gaseous phase. Indeed, to achieve a significant effect with ozone in gaseous form, longer exposure times and/or higher concentrations are needed $[8,52]$. However, it has been reported that molecules of ozone in gaseous form are characterized by a longer half-life and diffusion than molecules in an aqueous solution [54]. These characteristics could be exploited to counteract bacterial biofilm in the hard-to-reach areas of food plants [26].

\subsection{Legislation}

Nowadays, the legislation on the use of ozone as an alternative sanitization method varies among different countries. In USA, ozone has been classified as GRAS (Generally Recognized as Safe) since 1982 for the disinfection treatment of bottled water and in 1995 was used as a sanitizer for process trains in bottled water plants [52]. In 1997, ozone was declared as GRAS for direct contact with foods and in 2001 the FDA approved the use of ozone in gaseous and aqueous form as an antimicrobial for direct contact with different food matrices, including fish, meat, and poultry [52]. In the European Union, instead, there are no specific regulations about the use of the present technology on foods and in processing environments. In Italy, the use of gaseous ozone for the disinfection of cheese ripening rooms has been approved by the Ministry of Health, but the use at direct contact with cheese is not allowed [22]. In Japan, ozone has been used for the treatment of different food plants [55]. Ozone and relative treatments are permitted as processing aids in Australia, New Zealand, Russia, Armenia, Belarus, Kazakhstan, and Kyrgyzstan [8,52].

\subsection{Limitations: Toxicity, Effect on Foods and Equipment}

One of the main issues about the practical application of ozone is related to its toxicity. As ozone is toxic for humans, it is crucial to reduce the exposure of operators to minimize health risks. In this regard, the use of ozone destructors could be convenient when high concentrations are applied. Otherwise, treatments with high ozone concentrations may be applied in the absence of operators or during the weekly closing days [8,23]. In several countries, exposure limits are imposed in order to preserve the operators. In the USA and $\mathrm{UK}$, for example, a continuous exposure limit of $0.1 \mathrm{ppm}(8 \mathrm{~h} / \mathrm{day}, 40 \mathrm{~h} /$ week $)$ and $0.3 \mathrm{ppm}$ (15 min for a maximum of four times per day) [52] is permitted.

Another potential disadvantage of the ozone use in dairy industries is related to its effect on some food categories. Due to its high oxidative power, ozone could affect the stability of food containing high levels of fat. Sert et al. [56], as example, showed that ozone treatments resulted in a significative antimicrobial effect in butter but also in a decrease in the oxidative stability of the final product. Conversely, Segat et al. [57] showed that ozone treatments did not increase primary and secondary lipid oxidation products in mozzarella cheese. 
Another aspect to consider is the effect of ozone on the materials and equipment commonly used in the food industry. High concentrations of ozone, indeed, may cause the corrosion of these materials. In a study [58], the application of pulsed ozone in water at room temperature (20 $\mathrm{min}$ for seven days) resulted in weight loss of different materials, including aluminum, carbon steel, copper, and stainless steel (304 and 316), even if this weight loss was significantly greater $(\mathrm{a}=0.05)$ than the control samples only for carbon steel. Conversely, plastics frequently used in food industries, such as PTFE (Teflon), PVDF (Kynar), PVC, and ECTFE (Halar), exhibited resistance to corrosion after exposure to ozone [29]. Basically, treatments with ozone must always be optimized in relation to the materials to be treated, in order to avoid damage to the equipment in the production environment.

\subsection{Effect on Microbial Biofilms}

Few studies have investigated the effect of ozone in the prevention or removal of microbial biofilm. The mechanisms by which the ozone affects bacterial biofilms are still unclear. As highlighted by Moore et al., Gram-negative bacteria are usually more sensitive to ozone than Gram-positive microorganisms [59]. Panebianco et al. [26] hypothesized that a preventive application of ozone on L. monocytogenes planktonic cells reduces the capacity of bacteria to produce the extracellular polymeric matrix, while oxidative stress can lead to a reduction of the total biomass in preformed biofilm as a consequence of structural losses of the extracellular matrix. In this section, we report that the main spoilage and pathogenic bacterial groups able to form biofilms in the dairy environment. These main genera are reported also in Table 1. However, we must highlight that, in the dairy environment, mixed biofilms formed by both spoilage and pathogenic bacteria, such as L. monocytogenes and P. fluorescens, could often be detected [60].

Table 1. Bacteria able to form biofilms in the dairy environment.

\begin{tabular}{|c|c|c|c|}
\hline Genus & $\begin{array}{l}\text { Species Commonly Found in Dairy } \\
\text { Products and Environment }\end{array}$ & Problems & References \\
\hline Pseudomonas & $\begin{array}{l}\text { P. fluorescens, P. koreensis, } P \text {. marginalis, } \\
\text { P. rhodesiae, P. fragi, P. putida, P. entomophila, } \\
\text { P. mendocina, P. aeruginosa }\end{array}$ & $\begin{array}{l}\text { Spoilage: P. fluorescens, } P \text {. koreensis, } \\
\text { P. marginalis, } \\
\text { P. rhodesiae, P. fragi, P. putida, P. entomophila, } \\
\text { P. mendocina } \\
\text { Foodborne pathogens: } \text { P. aeruginosa }\end{array}$ & {$[33,61-63]$} \\
\hline Bacillus & $\begin{array}{l}\text { B. licheniformis, B. cereus, B. subtilis, } \\
\text { B. thuringiensis, B. weihenstephanensis, } \\
\text { B. mycoides, B. sporothermodurans, } \\
\text { B. megaterium }\end{array}$ & $\begin{array}{l}\text { Spoilage: B. licheniformis, B. cereus, B. subtilis, } \\
\text { B. thuringiensis, B. weihenstephanensis, } \\
\text { B. mycoides, } \\
\text { B. sporothermodurans, B. megaterium } \\
\text { Foodborne pathogens: B. cereus }\end{array}$ & [64-68] \\
\hline Clostridium & $\begin{array}{l}\text { C. tyrobutyricum, C. sporogenes, C. beijerinckii, } \\
\text { C. butyricum, C. botulinum, C. perfringens }\end{array}$ & $\begin{array}{l}\text { Spoilage: C. tyrobutyricum, C. sporogenes, } \\
\text { C. beijerinckii, C. butyricum } \\
\text { Foodborne pathogens: C. botulinum, } \\
\text { C. perfringens }\end{array}$ & [69-71] \\
\hline Cronobacter & C. sakazakii & Foodborne pathogen & {$[72,73]$} \\
\hline Listeria & L. monocytogenes & Foodborne pathogen & {$[26,45,46,74-77]$} \\
\hline Staphylococcus & S. aureus & Foodborne pathogen & [78-80] \\
\hline Salmonella & S. typhimurium, S. enterica & Foodborne pathogens & [81-86] \\
\hline Escherichia & Shiga toxin-producing E. coli (STEC) & Foodborne pathogens & [87-93] \\
\hline
\end{tabular}

In this section, readers can find relevant data about the action of ozone against the sessile form of bacteria of interest to the dairy industry; data are summarized in Table 2. 
Table 2. Data on the effect of ozone on biofilms formed by dairy-related spoilage and pathogenic bacteria.

\begin{tabular}{|c|c|c|c|c|c|}
\hline \multicolumn{2}{|c|}{ Target Microorganisms } & \multirow[t]{2}{*}{ Surface/Material } & \multirow[t]{2}{*}{ Treatment } & \multirow[t]{2}{*}{ Effect } & \multirow[t]{2}{*}{ Reference } \\
\hline Genus & Species & & & & \\
\hline \multirow[t]{3}{*}{ Pseudomonas } & P. fluorescens & Stainless steel & $\begin{array}{l}\text { Ozonated water } \\
(0.5 \mathrm{ppm} \text { for } 10 \mathrm{~min})\end{array}$ & $\begin{array}{l}\text { Loads Reduction } \\
(\sim 4 \text { Log10) }\end{array}$ & [94] \\
\hline & $\begin{array}{l}\text { P. fluorescens, } \\
\text { P. fragi, P. putida }\end{array}$ & Stainless steel & $\begin{array}{l}\text { Ozonated medium } \\
(0.6 \mathrm{ppm} \text { for } 10 \mathrm{~min})\end{array}$ & $\begin{array}{l}\text { Loads Reduction (from } \\
2.9 \text { to } 4.2 \log \text { CFU } / \mathrm{cm}^{2} \text { ) }\end{array}$ & [95] \\
\hline & P. fluorescens & Stainless steel & $\begin{array}{l}\text { (i) Static: ozonated water } \\
(0.5 \mathrm{mg} / \mathrm{L} \text { ) at } 20 \mathrm{~s}, 40 \mathrm{~s}, 1 \mathrm{~min} \text {, } \\
3 \mathrm{~min}, 5 \mathrm{~min}, 10 \mathrm{~min} \text {, and } \\
20 \mathrm{~min} \text {. (ii) Dynamic: flow of } \\
\text { ozonated water }(0.5 \mathrm{mg} / \mathrm{L}) \\
\text { for } 20 \mathrm{~s}, 40 \mathrm{~s}, 1 \mathrm{~min}, 3 \mathrm{~min} \text {, } \\
5 \mathrm{~min}, 10 \mathrm{~min} \text {, and } 20 \mathrm{~min} \text {. } \\
\text { (iii) Gaseous ozone: } \\
\text { concentrations of } 0.1,0.15 \text {, } \\
0.2,2,5 \text {, and } 20 \text { ppm for } \\
\text { exposure times of } 2,5,7,10 \text {, } \\
20,30 \text {, and } 60 \text { min. }\end{array}$ & $\begin{array}{l}\text { (i) Loads Reduction } \\
\left(\sim 1.56 \mathrm{Log} \text { CFU } / \mathrm{cm}^{2} \text { in }\right. \\
20 \mathrm{~min}) \text {; (ii) Loads } \\
\text { Reduction }(\sim 3.52 \mathrm{Log} \\
\left.\text { CFU } / \mathrm{cm}^{2} \text { in } 20 \mathrm{~min}\right) \text {; } \\
\text { (iii) Loads Reduction } \\
\left(\sim 5.51 \mathrm{Log} \text { CFU } / \mathrm{cm}^{2} \text { in }\right. \\
20 \mathrm{~min})\end{array}$ & [8] \\
\hline
\end{tabular}

Decrease of 2.3-2.6 logs after $1 \mathrm{~min}$ exposure to $4.5-5.6 \mathrm{mg} / \mathrm{mL}$. More

$\begin{array}{lll}\text { P. fluorescens } & \begin{array}{l}\text { Multilaminated } \\ \text { food packaging, } \\ \text { stainless steel }\end{array} & \begin{array}{l}\text { Aqueous ozone } \\ (3.7-12.9 \mathrm{mg} / \mathrm{mL})\end{array}\end{array}$
efficiency on stainless steel compared to the multilaminated packaging material (difference of 2-4 logs depending on the dosage of ozone)

Inactivation correlated to the concentration and the time (predicted D-values:

$\begin{array}{lll} & \text { Glass, } & \text { Dissolved ozone } \\ \text { P. aeruginosa } & \text { ceramic, } & (2,5 \text { and } 7 \text { ppm for } 10 \text { and } \\ & \text { plastic } & 20 \text { min })\end{array}$
$11.1,5.7$ and $2.2 \mathrm{~min}$ at 2,5 and 7 ppm, respectively). Inactivation (5 ppm for $20 \mathrm{~min}$ )

Sequential treatment

P. fluorescens Glass

(1.0 and $1.7 \mathrm{mg} / \mathrm{L}$ of ozone followed by 0.8 and $1.1 \%$ of

Significative effect on the survival ratio hydrogen peroxide)

\begin{tabular}{|c|c|}
\hline Bacillus & B. cereus \\
\hline
\end{tabular}

Greater action on stainless steel in the first $10 \mathrm{~min}$. Polypropylene: increase in the reduction with the exposure time, until 2.16 $\mathrm{Log} \mathrm{CFU} / \mathrm{cm}^{2}$ after $30 \mathrm{~min}$ 
Table 2. Cont.

\begin{tabular}{|c|c|c|c|c|c|}
\hline \multicolumn{2}{|c|}{ Target Microorganisms } & \multirow[t]{2}{*}{ Surface/Material } & \multirow[t]{2}{*}{ Treatment } & \multirow[t]{2}{*}{ Effect } & \multirow[t]{2}{*}{ Reference } \\
\hline Genus & Species & & & & \\
\hline & $\begin{array}{l}\text { B. subtilis, } \\
\text { B. amyloliquefa- } \\
\text { ciens }\end{array}$ & Stainless steel & $\begin{array}{l}\text { Gaseous ozone }(1.4 \mathrm{ppm}) \text { in } \\
\text { combination with cleaning in } \\
\text { place reagent }(\mathrm{NaOH})\end{array}$ & $\begin{array}{l}\text { Higher inactivation }(60 \\
\left.\text { and } 120^{\prime \prime}\right) \text { obtained with } \\
1.4 \text { ppm of ozone coupled } \\
\text { with } 1 \% \mathrm{NaOH} \text { as } \\
\text { compared to } \mathrm{NaOH}(1 \%) \\
\text { alone }\left(240^{\prime \prime}\right)\end{array}$ & [100] \\
\hline Listeria & L. monocytogenes & Polystyrene & $\begin{array}{l}\text { Ozonated water } \\
(1.0,2.0 \text {, and } 4.0 \text { ppm for } \\
1 \mathrm{~min})\end{array}$ & $\begin{array}{l}\sim 0.9,3.4 \text {, and } 4.1 \mathrm{Log} \\
\text { reduction }\end{array}$ & [101] \\
\hline
\end{tabular}

Attached cells eliminated at concentration of 4.00 ppm (7.47-log

L. monocytogenes Stainless steel Ozonated PPB (3 min) reduction). A fourfold increase in sanitizer concentration was required to destroy biofilm cells

Mean reduction of 3.41 Log10 CFU/ $\mathrm{cm}^{2}$ for stainless steel-attached

L. monocytogenes Stainless steel Gaseous ozone (45 ppm) cells after $1 \mathrm{~h}$. The same strains organized in biofilm were significantly more resistant

Reduction of sessile cells below the limit of detection (1.7 Log
L. monocytogenes
Polypropylene, stainless steel
Gaseous ozone (45 ppm)

$\mathrm{CFU} / \mathrm{cm}^{2}$ ) in $5 \mathrm{~min}$ on polypropylene; reduction of $3.4 \mathrm{Log} \mathrm{CFU} / \mathrm{cm}^{2}$ in stainless steel

Significant decrease of the biofilm biomass

$\begin{array}{lll}\text { L. monocytogenes } \quad \text { Polystyrene } & 6 \mathrm{~h}) & \begin{array}{l}\text { (colorimetric assay) for } \\ 59 \% \text { of the strains tested; } \\ \end{array} \\ & \begin{array}{l}\text { slight reduction of live } \\ \text { cells in the formed biofilm }\end{array}\end{array}$
cells in the formed biofilm

A continuous ozone flow $\left(1.07 \mathrm{mg} \mathrm{m}^{-3}\right)$ after 24 or $48 \mathrm{~h}$ of cold incubation

Glass, polypropylene, L. monocytogenes stainless steel, expanded polystyrene
Cold gaseous ozone resulted in the inactivation of 11 strains; with high inoculum level (9 log CFU coupon $^{-1}$ ) the best inactivation rate was observed after $48 \mathrm{~h}$ of treatment at $3.21 \mathrm{mg} \mathrm{m}^{-3}$ of ozone on stainless steel and expanded polystyrene 
Table 2. Cont.

\begin{tabular}{|c|c|c|c|c|c|}
\hline \multicolumn{2}{|c|}{ Target Microorganisms } & \multirow[t]{2}{*}{ Surface/Material } & \multirow[t]{2}{*}{ Treatment } & \multirow[t]{2}{*}{ Effect } & \multirow[t]{2}{*}{ Reference } \\
\hline Genus & Species & & & & \\
\hline & L. monocytogenes & Stainless steel & $\begin{array}{l}\text { Ozone in combination with } \\
\text { power ultrasound treatment }\end{array}$ & $\begin{array}{l}\text { Reductions of combined } \\
\text { treatments were } \\
\text { significantly }(p<0.05) \\
\text { higher than by either } \\
\text { treatment alone. No } \\
\text { recoverable cells after } 60 \mathrm{~s} \\
\text { of combined treatment } \\
\text { when an ozone } \\
\text { concentration of } 0.5 \mathrm{ppm} \\
\text { was used (7.31-log } \\
\text { CFU / mL reduction) }\end{array}$ & [105] \\
\hline \multirow[t]{2}{*}{ Staphylococcus } & S. aureus & Polypropylene & Ozonized water $(1 \mathrm{mg} / \mathrm{g})$ & $99 \%$ inactivation & [106] \\
\hline & S. aureus & Stainless steel & Ozonized water & $\begin{array}{l}\text { Reduction less than } \\
0.8 \text { Log CFU / cm } 2 \text { of } \\
\text { S. aureus and Salmonella } \\
\text { spp. biofilm after } \\
\text { exposure to ozonized } \\
\text { water for } 20 \mathrm{~min}\end{array}$ & [107] \\
\hline
\end{tabular}

(i) Static: ozonated water $(0.5 \mathrm{mg} / \mathrm{L})$ at $20 \mathrm{~s}, 40 \mathrm{~s}, 1 \mathrm{~min}$, $3 \mathrm{~min}, 5 \mathrm{~min}, 10 \mathrm{~min}$, and 20 min. (ii) Dynamic: flow of ozonated water $(0.5 \mathrm{mg} / \mathrm{L})$

S. aureus Stainless steel for $20 \mathrm{~s}, 40 \mathrm{~s}, 1 \mathrm{~min}, 3 \mathrm{~min}$, $5 \mathrm{~min}, 10 \mathrm{~min}$, and $20 \mathrm{~min}$. (iii) Gaseous ozone: concentrations of $0.1,0.15$, $0.2,2,5$, and $20 \mathrm{ppm}$ for exposure times of $2,5,7,10$, 20,30 , and $60 \mathrm{~min}$.

Methicillinresistant S. aureus Polystyrene (MRSA)
Ozonated oils (from 0.53 to $17 \mathrm{mg} / \mathrm{g}$ )
Highly sensitive to aqueous ozone treatment at dynamic conditions; exposure to gaseous ozone at high concentrations (20 ppm) resulted in a reduction of $4.72 \mathrm{Log}$ $\mathrm{CFU} / \mathrm{cm}^{2}$ of biofilm

Most strains inhibited at concentrations of $4.24 \mathrm{mg} / \mathrm{g}$. Removal of adherent cells and high capacity in the eradication of $24 \mathrm{~h}$ biofilms

S. Agona,

S. Infantis,

S. Typhimurium,

Salmonella

Stainless steel

Ozonized water

(Enteritidis

serotype),

S. Enteritidis

PVC pipes,

polyethylene, plastic, fresh produce
Reduction less than $0.8 \mathrm{Log} \mathrm{CFU} / \mathrm{cm}^{2}$ of S. aureus and Salmonella spp. biofilm after exposure to ozonized water for $20 \mathrm{~min}$

Reduction of biofilm formation on plastic bags and PVC pipes. In microtiter plates, reductions in biofilm formation were observed after $20 \mathrm{~h}$ and $40 \mathrm{~h}$ treatments 


\subsubsection{Pseudomonas}

The genus Pseudomonas includes bacteria that are able to cause several alterations in milk and dairy products. Specifically, Pseudomonas spp. are responsible for undesirable odors and flavors as well as unusual pigments of foods [61]. These microorganisms are ubiquitous; therefore, they are usually isolated at different production stages in the dairy environment. Species more commonly isolated from dairy plants are $P$. fluorescens, P. koreensis, P. marginalis, P. rhodesiae, P.fragi, P. putida, P. entomophila, P. mendocina, and $P$. aeruginosa [62]. Even if these bacteria are sensitive to thermal treatments commonly used in dairy processing, thermostable enzymes, such as proteases and lipases, could persist after treatments causing spoilage in finished products [33]. Several studies demonstrated that Pseudomonas isolates from milk, dairy products and dairy processing environments are able to form biofilm. In this regard, a recent study highlighted the relationship between biofilm formation abilities and the production of blue pigment of $P$. fluorescens dairy-related strains [63].

Several studies demonstrated how microorganisms belonging to this genus are generally susceptible to ozone exposure even when they are attached to common surfaces or organized in biofilms. As early as 1993, Greene et al. [94] showed that ozonated (0.5 ppm) water treatment (10 min exposure) was effective in reducing the loads $(\sim 4 \log 10)$ of common psychrotrophic spoilage bacteria, including P. fluorescens and Alcaligenes faecalis, on stainless steel surfaces, meanwhile highlighting that the effect of this technology was better performing than the commercial chlorinated sanitizers used in high concentration (100 ppm). Similarly, Dosti et al. [95] reported the effectiveness of ozone treatment (0.6 ppm for $10 \mathrm{~min}$ ) on P. fluorescens (ATCC 948), P. fragi (ATCC 4973), P. putida (ATCC 795), Enterobacter aerogenes (ATCC 35028), E. cloacae (ATCC 35030) and B. licheniformis (ATCC 14580) on stainless steel coupons. The sensitivity of $P$. fluorescens at ozone treatments was also shown by Marino et al. [8], which demonstrated the effectiveness of ozonated water (0.5 ppm) applied in static as well as dynamic conditions on biofilms. The authors also reported that ozone in gaseous form (20 ppm) led to a reduction of $5.51 \mathrm{Log} C F U / \mathrm{cm}^{2}$ after $60 \mathrm{~min}$ treatment. Khadre and Yousef [53] studied the effect of ozone on bacterial biofilms and dried films of B. subtilis spores and P. fluorescens in a multilaminated aseptic food packaging material and stainless steel. Ozone inactivated $P$. fluorescens in biofilms more effectively on stainless steel than on the multilaminated packaging material. Shelobolina et al. [96] studied the effect of dissolved ozone (2,5 and $7 \mathrm{ppm}$ for 10 and $20 \mathrm{~min}$ ) on P. aeruginosa biofilm grown on glass. The regression equation, used to analyze the effect of ozone, highlighted that biofilm inactivation was correlated to the concentration and the contact time (predicted D-values: 11.1, 5.7 and $2.2 \mathrm{~min}$ at 2, 5 and $7 \mathrm{ppm}$, respectively). The same authors studied the inactivation of biofilms on various surfaces by dissolved ozone ( $5 \mathrm{ppm}$ for $20 \mathrm{~min}$ ). The outcomes emphasized that biofilms grown on ceramics were more difficult to inactivate than those grown on plastic materials. Ozone can also be effective on Pseudomonas biofilm in combination with other technologies. For example, ozone water in combination with a hydrogen peroxide solution was effective on $P$. fluorescens biofilm. In this regard, a sequential treatment with 1.0 and $1.7 \mathrm{mg} / \mathrm{L}$ of ozone followed by 0.8 and $1.1 \%$ of hydrogen peroxide showed synergistic disinfection effects [97].

\subsubsection{Bacillus}

Among spore-forming bacteria, the genus Bacillus is of high importance, since it includes bacteria that can cause spoilage in milk and dairy products, as well as foodborne pathogens. Bacillus species are ubiquitous, Gram-positive, motile, and rod-shaped bacteria, characterized by high versatility and adaptability to different environmental conditions and can survive during the different stages of processing and manufacturing of dairy products [64]. The most common species found in dairy environments are B. licheniformis, B. cereus, B. subtilis, B. thuringiensis, B. weihenstephanensis, B. mycoides, B. sporothermodurans, and B. megaterium [64-66]. Bacillus are able to adhere and persist on different surfaces; in addition, they can form other biofilm types, including bundles in the liquid phase and 
pellicles at the air-liquid interface [67,68]. Additionally, Bacillus can form heat-resistant spores that can survive after the routinary pasteurization processes.

Different studies have emphasized how ozone is effective on biofilms formed by dairyrelated Bacillus. A recent researchdemonstrated the efficacy of gaseous ozone treatment (45 $\pm 2 \mathrm{ppm}$ ) on B. cereus biofilms formed on stainless steel and polypropylene [98]. Another study evaluated the effect of ozonated water on B. cereus biofilms grown on dairy processing membranes and highlighted an average reduction of $1.0 \mathrm{Log} \mathrm{CFU} / \mathrm{cm}^{2}$ for treated membranes [99]. The efficacy of ozone, in combination with cleaning in place reagent $(\mathrm{NaOH})$, was shown on biofilms formed by B. subtilis and B. amyloliquefaciens on stainless steel. Higher inactivation of biofilms (60 and 120") was obtained with $1.4 \mathrm{ppm}$ of ozone coupled with $1 \% \mathrm{NaOH}$ as compared to $\mathrm{NaOH}$ alone, which required $240 \mathrm{~s}$ to completely remove the film from the stainless steel coupons [100].

\subsubsection{Listeria}

This genus comprises one of the most studied bacteria worldwide, that is L. monocytogenes. L. monocytogenes is a Gram-positive foodborne pathogen. This pathogen, when organized in established biofilms, can persist over a long period of time on surfaces and food processing environments, thus representing a potential cause of repeated contaminations of the finished products [74-76]. Detection of biofilm forming and persistent L. monocytogenes strains in the dairy environment was reported in several studies [45,46]. It has been demonstrated that adhesion capacity and biofilm formation abilities differ among several L. monocytogenes strains. This strain variability seems to be linked with the presence of specific genes and/or accessory genetic elements, such as phages, plasmids and stress survival islets $[26,77]$.

Several experiments have been performed so far on L. monocytogenes biofilm, highlighting that high ozone levels and long exposure times are needed to achieve an effect against biofilms formed by this bacterium. Korany et al. [101] reported that ozonated water treatment (1 min at 1.0, 2.0 and $4.0 \mathrm{ppm}$ ) resulted in $\sim 0.9,3.4$ and $4.1 \log$ reduction of $L$. monocytogenes single strain biofilm on polystyrene, but the effect was lower with multi-strain biofilms and in the presence of organic matter. Robbins et al. [102] obtained a complete elimination of attached L. monocytogenes Scott A and 10403S strains cells after exposure to 4 ppm of ozone. Nicholas et al. [103] reported a mean reduction of $3.41 \mathrm{Log} 10 \mathrm{CFU} / \mathrm{cm}^{2}$ for stainless steel-attached L. monocytogenes cells after $1 \mathrm{~h}$ treatment at $45 \mathrm{ppm}$ of gaseous ozone, but the same strains organized in biofilm were significantly more resistant after a treatment with ozone gas at $45 \mathrm{ppm}$ for $1 \mathrm{~h}$. Harada et al. [104] demonstrated the efficiency of gaseous ozone (45 ppm) as a dry sanitizing method on L. monocytogenes. The authors observed a reduction of sessile cells below the limit of detection $\left(1.7 \mathrm{Log} \mathrm{CFU} / \mathrm{cm}^{2}\right)$ in $5 \mathrm{~min}$ on polypropylene, while a reduction of $3.4 \mathrm{Log} \mathrm{CFU} / \mathrm{cm}^{2}$ was observed in stainless steel. A recent experiment conducted on dairy- and meat-related L. monocytogenes showed that ozone gas in high concentrations ( $50 \mathrm{ppm}$ for $6 \mathrm{~h}$ ) caused a significant decrease of the biofilm biomass for $59 \%$ of the strains tested, but only a slight reduction of live cells in the formed biofilm was observed [26]. De Candia et al. [21] demonstrated the efficacy of cold gaseous ozone treatments at low concentrations in the eradication of L. monocytogenes from different food contact surfaces (glass, polypropylene, stain-less steel, expanded polystyrene). A continuous ozone flow $\left(1.07 \mathrm{mg} \mathrm{m}^{-3}\right)$ after 24 or $48 \mathrm{~h}$ of cold incubation resulted in the inactivation of 11 strains, while with higher inoculum levels $\left(9 \log\right.$ CFU coupon $\left.{ }^{-1}\right)$ the best inactivation rate was detected after $48 \mathrm{~h}$ of treatment at $3.21 \mathrm{mg} \mathrm{m}^{-3}$ of ozone on stainless steel and expanded polystyrene. Baumann et al. [105] tested ozone (concentrations of $0.25,0.5$ and $1.0 \mathrm{ppm}$ ) in combination with power ultrasound cycled through $250 \mathrm{~mL}$ of a potassium phosphate buffer containing L. monocytogenes biofilm chips for 30 or $60 \mathrm{~s}$. Reductions obtained with the combined treatments were significantly $(p<0.05)$ higher than each treatment alone. No recoverable cells were detected (reduction $=7.31 \mathrm{Log} \mathrm{CFU} / \mathrm{mL}$ ) after $60 \mathrm{~s}$ of the combined treatment when ozone was used at a concentration of $0.5 \mathrm{ppm}$. 


\subsubsection{Staphylococcus}

S. aureus is deemed as an important pathogen detectable in dairy products. Several studies showed how this bacterium can form biofilm in the dairy environment. Lee et al. [78] studied the biofilm production abilities of strains isolated from milking parlor environments on dairy farms in Brazil. Around $45 \%$ of S. aureus pulsotypes were able to form biofilms in at least one assay, suggesting their possible persistence in milking environments. Biofilm forming abilities were demonstrated also for dairy-related $S$. aureus isolated from Switzerland and Italy, including methicillin-resistant S. aureus (MRSA) [79], and for strains isolated from food-contact surfaces in dairy industries in Mexico [80].

S. aureus is generally sensitive to ozone exposure. Cabo et al. demonstrated that the application of $1 \mu \mathrm{g} / \mathrm{g}$ of ozonized water allowed $99 \%$ inactivation in $2 \mathrm{~min}$ of S. aureus CECT4459 biofilm on polypropylene [106]. Shao et al. [107] studied the effect of ozone water on mature S. aureus and Salmonella spp. biofilm, detecting less than $0.8 \mathrm{Log} \mathrm{cfu} / \mathrm{cm}^{2}$ of cells reduction in biofilm exposed to ozonized water for $20 \mathrm{~min}$. In the study performed by Marino et al. [8], S. aureus was highly responsive to aqueous ozone treatments at dynamic conditions, while exposure to gaseous ozone at high concentrations (20 ppm) resulted in a reduction of $4.72 \mathrm{Log} C F U / \mathrm{cm}^{2}$ of $S$. aureus biofilm. A recent study investigated the effect of ozonated oils with concentrations ranging from 0.53 to $17 \mathrm{mg} / \mathrm{g}$ on Methicillin-resistant S. aureus (MRSA) biofilm; most strains were inhibited at concentrations of $4.24 \mathrm{mg} / \mathrm{g}$. Additionally, ozonated oils showed ability in removing adherent cells and high capacity in the eradication of $24 \mathrm{~h}$ biofilms [108].

\subsubsection{Salmonella}

The genus Salmonella includes well known pathogenic bacteria which can be found in different types of foods. Historically, several Salmonella outbreaks were linked to the consumption of dairy products, especially raw milk products [81-83]. Bacteria of this genus, indeed, can persist in fresh and fermented dairy products for their adaptation to an acid environment. Leyer and Johnson [84] demonstrated that acid-adapted S. typhimurium cells had increased resistance to organic acids usually present in cheese, such as lactic, propionic, and acetic acid. In a study of Kessel et al. [85], Salmonella was isolated from 36 of 75 PCR-positive bulk tank milk samples and 105 of 174 PCR-positive milk filter samples. Lamas et al. [86] proved that milk residues are a source of nutrients for S. enterica biofilm formation on stainless steel and that the biofilm forming abilities of this bacterium are strongly related to oxygen levels.

Few studies exist about the effectiveness of ozone treatments against biofilms formed by bacteria belonging to this genus. Shao et al. [107] reported a reduction less than $0.8 \mathrm{Log} \mathrm{cfu} / \mathrm{cm}^{2}$ of S. aureus and Salmonella spp. biofilm after exposure to ozonized water for $20 \mathrm{~min}$. In another study [109], the effect of malic acid and ozone against $S$. typhimurium biofilm on different food contact surfaces (PVC pipes, polyethylene, plastic, and fresh produce) was explored. The mutual effect of malic acid with ozone resulted in a reduction of biofilm formation on plastic bags and PVC pipes. In microtiter plates, reductions in biofilm formation were observed after $20 \mathrm{~h}$ and $40 \mathrm{~h}$ treatments.

\subsubsection{Clostridium, Cronobacter, Escherichia}

The genus Clostridium includes Gram-positive spore-forming anaerobes bacteria that can induce spoilage of dairy products by gas production arising from the fermentation of acetate, lactate, and butyrate $[69,70]$. C. tyrobutyricum is considered the species most frequently involved in cheese spoilage, as it is the causative agent of the so called "late blowing defect", though C. sporogenes, C. beijerinckii, C. tyrobutyricum, and C. butyricum can also cause cheese alterations [69,70]. Additionally, this genus includes pathogenic bacteria, such as $C$. botulinum and C. perfringens. A recent study showed that dairy-related C. perfringens isolates were able to form biofilm at different temperatures $(4,25$, and $35^{\circ} \mathrm{C}$ ) [71]. The genus Cronobacter comprises $C$. sakazakii, a relevant foodborne pathogen included in the food safety criteria for infant foods in the Regulation EC 2073/05 and 
amendments [110]. This bacterium is characterized by high adaptability to the dairy environment. This aspect was emphasized by Oh et al. [72], which studied the biofilmforming abilities of 72 strains on plastic surfaces, as well as the influence of the artificial growth medium and infant milk formula (IMF). The diversity and biofilm forming abilities of Cronobacter isolated in New Zealand were investigated by Gupta et al. [73], which showed that adherence characteristics are related with nutrients and temperature. The genus Escherichia includes relevant foodborne pathogens associated with dairy products, such as the enterohemorrhagic E. coli O157:H7. Several studies demonstrated that this bacterium could survive in different types of dairy products, and E. coli O157:H7 outbreaks frequently occurred after consumption of unpasteurized cheese [87-90]. Sharma and Anand analyzed biofilms of pasteurization lines in a commercial plant and in an experimental dairy plant, revealing the presence of E. coli in both cases [91]. The high biofilm forming abilities of different Shiga toxin-producing E. coli (STEC) and the strong tolerance to common sanitizers led to concerns regarding the colonization of surfaces and the resultant downstream food contamination [92,93].

To the best of our knowledge, no relevant studies describing the effect of gaseous ozone against biofilms of these bacteria have been conducted, while the effect of ozone on the vegetative and spore forms is well documented. Foegeding [111] studied the effect of ozone on spores of C. perfringens NCTC 8798 and C. botulinum 12885A strains, highlighting how ozone was an effective sporicide, especially at acidic $\mathrm{pH}$ values. The action of ozone improved the efficiency of cooking temperatures (from 45 to $75^{\circ} \mathrm{C}$ ) against C. perfringens on beef surfaces [112]. Significant reductions of vegetative cells (from $5.59 \pm 0.17$ to $4.09 \pm 0.72$ and $3.50 \pm 0.90 \log$ CFU /g after treatments with aqueous ozone at 5 ppm and heating at 45 and $55^{\circ} \mathrm{C}$ ) were reported. Spores, indeed, were reduced from $2.94 \pm 0.37 \mathrm{log}$ spores $/ \mathrm{g}$ to $2.07 \pm 0.38 \log$ spores $/ g$ and $1.70 \pm 0.37 \mathrm{log}$ spores $/ \mathrm{g}$ after the treatments with $5 \mathrm{ppm}$ of aqueous ozone and heating at 55 and $75^{\circ} \mathrm{C}$, respectively. Gaseous ozone was effective in the inactivation of Cronobacter in milk powders. A continuous stream of ozone led to a reduction of 2.71 and $3.28 \log$ after $120 \mathrm{~min}$ at 2.8 and $5.3 \mathrm{mg} / \mathrm{L}^{-1}$, respectively [113]. With regards to Escherichia, a study carried out in 2010 did not reveal any significative effect of ozone (2 $\mathrm{mg} / \mathrm{L}$ ) in removing E. coli and L. monocytogenes cells in biofilms on lettuce surfaces [114]. However, in the study of de Oliveira Souza et al. [115], ozonated water (35 and $45 \mathrm{mg} / \mathrm{L}^{-1}$ for $0,5,15$, and $25 \mathrm{~min}$ ) was effective in inactivating E. coli O157:H7, while reductions of $1.5 \mathrm{log}$ cycles were detected in lactose-free homogenized skim milk, indicating the influence of the substrate on the antimicrobial efficiency of ozone. Effectiveness of aqueous ozone treatment $(5 \mathrm{mg} / \mathrm{L})$ on Shiga toxin-producing E. coli inoculated in alfalfa seeds was demonstrated by Mohammad et al. [116], who reported mean log reductions of $1.5 \pm 0.4$, $1.6 \pm 0.4,2.1 \pm 0.5$ after 10,15 , and $20 \mathrm{~min}$, respectively.

\section{Conclusions}

The maintenance of good hygienic conditions in the working environment is crucial to avoid microbial contamination by spoilage or pathogenic bacteria of dairy products. Although some reviews have been published on the use of ozone in controlling microbial contamination in the food industry, to our knowledge, this is the first review focused on the effect of ozone against microbial biofilms, commonly found in dairy plants. Currently, data concerning the efficacy of ozone as an anti-biofilm agent in the food context suggest that the anti-biofilm action is variable and still not completely investigated. The advantages of using ozone in dairy processing plants include the low environmental impact, which comprise the absence of harmful residuals in food products or on contact surfaces. Nevertheless, further studies are needed to evaluate its action in preventing or removing microbial biofilm both in experimental and under realistic environmental conditions. Finally, since ozone application has several limitations (toxicity, potential effect on materials and high-fat foods), restrictions and detailed application protocols should be applied in relation to the specific needs and characteristics of dairy processing environments. 


\begin{abstract}
Author Contributions: F.P.: investigation, writing-original draft. S.R.: investigation, writing一review and editing; P.A.D.C.: supervision; writing - review and editing. All authors have read and agreed to the published version of the manuscript.
\end{abstract}

Funding: This research received no external funding.

Institutional Review Board Statement: Not applicable.

Informed Consent Statement: Not applicable.

Conflicts of Interest: The authors declare no conflict of interest.

\title{
References
}

1. Galiè, S.; García-Gutiérrez, C.; Miguélez, E.M.; Villar, C.J.; Lombó, F. Biofilms in the Food Industry: Health Aspects and Control Methods. Front. Microbiol. 2018, 9, 898. [CrossRef] [PubMed]

2. González-Rivas, F.; Ripolles-Avila, C.; Fontecha-Umaña, F.; Ríos-Castillo, A.G.; Rodríguez-Jerez, J.J. Biofilms in the Spotlight: Detection, Quantification, and Removal Methods. Compr. Rev. Food Sci. Food Saf. 2018, 17, 1261-1276. [CrossRef] [PubMed]

3. Abebe, G.M. The Role of Bacterial Biofilm in Antibiotic Resistance and Food Contamination. Int. J. Microbiol. 2020, 2020, 1-10. [CrossRef]

4. Srey, S.; Jahid, I.K.; Ha, S.-D. Biofilm formation in food industries: A food safety concern. Food Control 2013, 31, 572-585. [CrossRef]

5. Brooks, J.D.; Flint, S.H. Biofilms in the food industry: Problems and potential solutions. Int. J. Food Sci. Technol. 2008, 43, 2163-2176. [CrossRef]

6. $\quad$ Flint, S.; Bremer, P.; Brooks, J.; Palmer, J.; Sadiq, F.A.; Seale, B.; Teh, K.H.; Wu, S.; Zain, S.N.M. Bacterial fouling in dairy processing. Int. Dairy J. 2020, 101, 104593. [CrossRef]

7. Wassenaar, T.M.; Ussery, D.; Nielsen, L.N.; Ingmer, H. Review and phylogenetic analysis ofqacgenes that reduce susceptibility to quaternary ammonium compounds in Staphylococcus species. Eur. J. Microbiol. Immunol. 2015, 5, 44-61. [CrossRef]

8. Marino, M.; Maifreni, M.; Baggio, A.; Innocente, N. Inactivation of Foodborne Bacteria Biofilms by Aqueous and Gaseous Ozone. Front. Microbiol. 2018, 9, 2024. [CrossRef]

9. Oniciuc, E.A.; Likotrafiti, E.; Alvarez-Molina, A.; Prieto, M.; López, M.; Alvarez-Ordóñez, A. Food processing as a risk factor for antimicrobial resistance spread along the food chain. Curr. Opin. Food Sci. 2019, 30, 21-26. [CrossRef]

10. Martínez-Suárez, J.V.; Ortiz, S.; López-Alonso, V. Potential Impact of the Resistance to Quaternary Ammonium Disinfectants on the Persistence of Listeria monocytogenes in Food Processing Environments. Front. Microbiol. 2016, 7, 638. [CrossRef]

11. Møretrø, T.; Schirmer, B.C.; Heir, E.; Fagerlund, A.; Hjemli, P.; Langsrud, S. Tolerance to quaternary ammonium compound disinfectants may enhance growth of Listeria monocytogenes in the food industry. Int. J. Food Microbiol. 2017, 241, 215-224. [CrossRef]

12. Guérin, A.; Bridier, A.; Le Grandois, P.; Sévellec, Y.; Palma, F.; Félix, B.; LISTADAPT Study Group; Roussel, S.; Soumet, C. Exposure to Quaternary Ammonium Compounds Selects Resistance to Ciprofloxacin in Listeria monocytogenes. Pathogens 2021, 10, 220. [CrossRef]

13. Rubiola, S.; Chiesa, F.; Dalmasso, A.; Di Ciccio, P.; Civera, T. Detection of Antimicrobial Resistance Genes in the Milk Production Environment: Impact of Host DNA and Sequencing Depth. Front. Microbiol. 2020, 11, 11. [CrossRef]

14. Colagiorgi, A.; Festa, R.; Di Ciccio, P.A.; Gogliettino, M.; Balestrieri, M.; Palmieri, G.; Anastasio, A.; Ianieri, A. Rapid biofilm eradication of the antimicrobial peptide 1018-K6 against Staphylococcus aureus: A new potential tool to fight bacterial biofilms. Food Control. 2020, 107, 106815. [CrossRef]

15. Friedlander, A.; Nir, S.; Reches, M.; Shemesh, M. Preventing Biofilm Formation by Dairy-Associated Bacteria Using PeptideCoated Surfaces. Front. Microbiol. 2019, 10, 1405. [CrossRef] [PubMed]

16. Meireles, A.; Borges, A.; Giaouris, E.; Simões, M. The current knowledge on the application of anti-biofilm enzymes in the food industry. Food Res. Int. 2016, 86, 140-146. [CrossRef]

17. Zhu, Y.; Li, C.; Cui, H.; Lin, L. Feasibility of cold plasma for the control of biofilms in food industry. Trends Food Sci. Technol. 2020, 99, 142-151. [CrossRef]

18. Masotti, F.; Vallone, L.; Ranzini, S.; Silvetti, T.; Morandi, S.; Brasca, M. Effectiveness of air disinfection by ozonation or hydrogen peroxide aerosolization in dairy environments. Food Control. 2019, 97, 32-38. [CrossRef]

19. Varga, L.; Szigeti, J. Use of ozone in the dairy industry: A review. Int. J. Dairy Technol. 2016, 69, 157-168. [CrossRef]

20. Pascual, A.; Llorca, I.; Canut, A. Use of ozone in food industries for reducing the environmental impact of cleaning and disinfection activities. Trends Food Sci. Technol. 2007, 18, S29-S35. [CrossRef]

21. De Candia, S.; Morea, M.; Baruzzi, F. Eradication of high viable loads of Listeria monocytogenes contaminating food-contact surfaces. Front. Microbiol. 2015, 6, 733. [CrossRef] [PubMed]

22. Bigi, F.; Haghighi, H.; Quartieri, A.; De Leo, R.; Pulvirenti, A. Impact of low-dose gaseous ozone treatment to reduce the growth of in vitro broth cultures of foodborne pathogenic/spoilage bacteria in a food storage cold chamber. J. Food Saf. 2021, 41, e12892. [CrossRef] 
23. Botta, C.; Ferrocino, I.; Pessione, A.; Cocolin, L.; Rantsiou, K. Spatiotemporal Distribution of the Environmental Microbiota in Food Processing Plants as Impacted by Cleaning and Sanitizing Procedures: The Case of Slaughterhouses and Gaseous Ozone. Appl. Environ. Microbiol. 2020, 86, 86. [CrossRef]

24. Sivaranjani, S.; Prasath, V.A.; Pandiselvam, R.; Kothakota, A.; Khaneghah, A.M. Recent advances in applications of ozone in the cereal industry. LWT 2021, 146, 111412. [CrossRef]

25. Carpentier, B.; Cerf, O. Review-Persistence of Listeria monocytogenes in food industry equipment and premises. Int. J. Food Microbiol. 2011, 145, 1-8. [CrossRef] [PubMed]

26. Panebianco, F.; Rubiola, S.; Chiesa, F.; Civera, T.; Di Ciccio, P. Effect of Gaseous Ozone on Listeria monocytogenes Planktonic Cells and Biofilm: An In Vitro Study. Foods 2021, 10, 1484. [CrossRef] [PubMed]

27. Guzel-Seydim, Z.B.; Greene, A.K.; Seydim, A. Use of ozone in the food industry. LWT 2004, 37, 453-460. [CrossRef]

28. Pandiselvam, R.; Subhashini, S.; Priya, E.B.; Kothakota, A.; Ramesh, S.; Shahir, S. Ozone based food preservation: A promising green technology for enhanced food safety. Ozone Sci. Eng. 2019, 41, 17-34. [CrossRef]

29. Brodowska, A.J.; Nowak, A.; Śmigielski, K.B. Ozone in the food industry: Principles of ozone treatment, mechanisms of action, and applications: An overview. Crit. Rev. Food Sci. Nutr. 2018, 58, 2176-2201. [CrossRef]

30. Afonso, R.; Moreira, R.; de Almeida, P. Can ozone be used as antimicrobial in the dairy industry? A systematic review. J. Dairy Sci. 2021. [CrossRef] [PubMed]

31. Marchand, S.; De Block, J.; De Jonghe, V.; Coorevits, A.; Heyndrickx, M.; Herman, L. Biofilm Formation in Milk Production and Processing Environments; Influence on Milk Quality and Safety. Compr. Rev. Food Sci. Food Saf. 2012, 11, 133-147. [CrossRef]

32. Teh, K.H.; Flint, S.; Palmer, J.; Lindsay, D.; Andrewes, P.; Bremer, P. Thermo-resistant enzyme-producing bacteria isolated from the internal surfaces of raw milk tankers. Int. Dairy J. 2011, 21, 742-747. [CrossRef]

33. Zhang, C.; Bijl, E.; Svensson, B.; Hettinga, K. The Extracellular Protease AprX from Pseudomonas and its Spoilage Potential for UHT Milk: A Review. Compr. Rev. Food Sci. Food Saf. 2019, 18, 834-852. [CrossRef] [PubMed]

34. Teh, K.H.; Flint, S.; Palmer, J.; Andrewes, P.; Bremer, P.; Lindsay, D. Biofilm-An unrecognised source of spoilage enzymes in dairy products? Int. Dairy J. 2014, 34, 32-40. [CrossRef]

35. Latorre, A.; Van Kessel, J.; Karns, J.; Zurakowski, M.; Pradhan, A.; Boor, K.; Jayarao, B.; Houser, B.; Daugherty, C.; Schukken, Y. Biofilm in milking equipment on a dairy farm as a potential source of bulk tank milk contamination with Listeria monocytogenes. $J$. Dairy Sci. 2010, 93, 2792-2802. [CrossRef]

36. Pacha, P.; Munoz, M.; González-Rocha, G.; Martín, I.S.; Quezada-Aguiluz, M.; Aguayo-Reyes, A.; Bello-Toledo, H.; Latorre, A. Molecular diversity of Staphylococcus aureus and the role of milking equipment adherences or biofilm as a source for bulk tank milk contamination. J. Dairy Sci. 2021, 104, 3522-3531. [CrossRef]

37. Jaakkonen, A.; Kivistö, R.; Aarnio, M.; Kalekivi, J.; Hakkinen, M. Persistent contamination of raw milk by Campylobacter jejuni ST-883. PLoS ONE 2020, 15, e0231810. [CrossRef]

38. Anand, S.; Singh, D.; Avadhanula, M.; Marka, S. Development and Control of Bacterial Biofilms on Dairy Processing Membranes. Compr. Rev. Food Sci. Food Saf. 2014, 13, 18-33. [CrossRef]

39. Chen, C.-L.; Liu, W.-T.; Chong, M.-L.; Wong, M.-T.; Ong, S.L.; Seah, H.; Ng, W.J. Community structure of microbial biofilms associated with membrane-based water purification processes as revealed using a polyphasic approach. Appl. Microbiol. Biotechnol. 2004, 63, 466-473. [CrossRef]

40. Chamberland, J.; Lessard, M.-H.; Doyen, A.; Labrie, S.; Pouliot, Y. A sequencing approach targeting the 16S rRNA gene unravels the biofilm composition of spiral-wound membranes used in the dairy industry. Dairy Sci. Technol. 2017, 96, 827-843. [CrossRef]

41. Jindal, S.; Anand, S.; Metzger, L.; Amamcharla, J. Short communication: A comparison of biofilm development on stainless steel and modified-surface plate heat exchangers during a 17-h milk pasteurization run. J. Dairy Sci. 2018, 101, 2921-2926. [CrossRef] [PubMed]

42. Sharma, M.; Anand, S. Biofilms evaluation as an essential component of HACCP for food/dairy processing industry-A case Food Control 2002, 13, 469-477. [CrossRef]

43. Mugadza, D.T.; Owusu-Darko, R.; Buys, E.M. Short communication: Source tracking Bacillus cereus in an extended-shelf-life milk processing plant using partial sequencing of rpoB and multilocus sequence typing. J. Dairy Sci. 2019, 102, 135-139. [CrossRef] [PubMed]

44. Weber, M.; Liedtke, J.; Plattes, S.; Lipski, A. Bacterial community composition of biofilms in milking machines of two dairy farms assessed by a combination of culture-dependent and -independent methods. PLoS ONE 2019, 14, e0222238. [CrossRef]

45. Lee, S.H.I.; Barancelli, G.V.; de Camargo, T.M.; Corassin, C.H.; Rosim, R.E.; da Cruz, A.G.; Cappato, L.P.; de Oliveira, C.A.F. Biofilm-producing ability of Listeria monocytogenes isolates from Brazilian cheese processing plants. Food Res. Int. 2017, $91,88-91$. [CrossRef] [PubMed]

46. Costa, A.; Bertolotti, L.; Brito, L.; Civera, T. Biofilm Formation and Disinfectant Susceptibility of Persistent and Nonpersistent Listeria monocytogenes Isolates from Gorgonzola Cheese Processing Plants. Foodborne Pathog. Dis. 2016, 13, 602-609. [CrossRef]

47. Panebianco, F.; Giarratana, F.; Caridi, A.; Sidari, R.; De Bruno, A.; Giuffrida, A. Lactic acid bacteria isolated from traditional Italian dairy products: Activity against Listeria monocytogenes and modelling of microbial competition in soft cheese. LWT 2020, 137, 110446. [CrossRef] 
48. Salomskiene, J.; Jonkuviene, D.; Macioniene, I.; Abraitiene, A.; Zeime, J.; Repeckiene, J.; Vaiciulyte-Funk, L. Differences in the occurence and efficiency of antimicrobial compounds produced by lactic acid bacteria. Zeitschrift Untersuchung Nahrungs Genußmittel 2019, 245, 569-579. [CrossRef]

49. Didienne, R.; Defargues, C.; Callon, C.; Meylheuc, T.; Hulin, S.; Montel, M.-C. Characteristics of microbial biofilm on wooden vats ('gerles') in PDO Salers cheese. Int. J. Food Microbiol. 2012, 156, 91-101. [CrossRef]

50. Gaglio, R.; Cruciata, M.; Scatassa, M.L.; Tolone, M.; Mancuso, I.; Cardamone, C.; Corona, O.; Todaro, M.; Settanni, L. Influence of the early bacterial biofilms developed on vats made with seven wood types on PDO Vastedda della valle del Belìce cheese characteristics. Int. J. Food Microbiol. 2019, 291, 91-103. [CrossRef]

51. Margalit, M.; Attias, E.; Attias, D.; Elstein, D.; Zimran, A.; Matzner, Y. Effect of ozone on neutrophil function in vitro. Int. J. Lab. Hematol. 2001, 23, 243-247. [CrossRef]

52. Baggio, A.; Marino, M.; Innocente, N.; Celotto, M.; Maifreni, M. Antimicrobial effect of oxidative technologies in food processing: An overview. Eur. Food Res. Technol. 2020, 246, 669-692. [CrossRef]

53. Khadre, M.A.; Yousef, A.E. Decontamination of a Multilaminated Aseptic Food Packaging Material and Stainless Steel by Ozone. J. Food Saf. 2001, 21, 1-13. [CrossRef]

54. Giménez, B.; Graiver, N.; Giannuzzi, L.; Zaritzky, N. Treatment of beef with gaseous ozone: Physicochemical aspects and antimicrobial effects on heterotrophic microflora and Listeria monocytogenes. Food Control 2021, 121, 107602. [CrossRef]

55. Naito, S.; Takahara, H. Ozone Contribution in Food Industry in Japan. Ozone Sci. Eng. 2006, 28, 425-429. [CrossRef]

56. Sert, D.; Mercan, E.; Kara, Ü. Butter production from ozone-treated cream: Effects on characteristics of physicochemical, microbiological, thermal and oxidative stability. LWT 2020, 131, 109722. [CrossRef]

57. Segat, A.; Biasutti, M.; Iacumin, L.; Comi, G.; Baruzzi, F.; Carboni, C.; Innocente, N. Use of ozone in production chain of high moisture Mozzarella cheese. LWT Food Sci. Technol. 2014, 55, 513-520. [CrossRef]

58. Greene, A.K.; Smith, G.; Knight, C.S. Ozone in dairy chilling water systems: Effect on metal materials. Int. J. Dairy Technol. 1999, 52, 126-128. [CrossRef]

59. Moore, G.; Griffith, C.; Peters, A. Bactericidal Properties of Ozone and Its Potential Application as a Terminal Disinfectant. J. Food Prot. 2000, 63, 1100-1106. [CrossRef]

60. Maggio, F.; Rossi, C.; Chaves-López, C.; Serio, A.; Valbonetti, L.; Pomilio, F.; Chiavaroli, A.; Paparella, A. Interactions between L. monocytogenes and P. fluorescens in Dual-Species Biofilms under Simulated Dairy Processing Conditions. Foods 2021, 10, 176. [CrossRef] [PubMed]

61. Reichler, S.; Murphy, S.; Martin, N.; Wiedmann, M. Identification, subtyping, and tracking of dairy spoilage-associated Pseudomonas by sequencing the ileS gene. J. Dairy Sci. 2021, 104, 2668-2683. [CrossRef] [PubMed]

62. Chiesa, F.; Lomonaco, S.; Nucera, D.; Garoglio, D.; Dalmasso, A.; Civera, T. Distribution of Pseudomonas species in a dairy plant affected by occasional blue discoloration. Ital. J. Food Saf. 2014, 3, 1722. [CrossRef] [PubMed]

63. Rossi, C.; Serio, A.; Chaves-López, C.; Anniballi, F.; Auricchio, B.; Goffredo, E.; Cenci-Goga, B.T.; Lista, F.; Fillo, S.; Paparella, A. Biofilm formation, pigment production and motility in Pseudomonas spp. isolated from the dairy industry. Food Control 2018, 86, 241-248. [CrossRef]

64. Shemesh, M.; Ostrov, I. Role of Bacillus species in biofilm persistence and emerging antibiofilm strategies in the dairy industry. $J$. Sci. Food Agric. 2020, 100, 2327-2336. [CrossRef] [PubMed]

65. Egopal, N.; Hill, C.; Ross, R.; Beresford, T.P.; Fenelon, M.; Cotter, P.D. The Prevalence and Control of Bacillus and Related Spore-Forming Bacteria in the Dairy Industry. Front. Microbiol. 2015, 6, 1418. [CrossRef]

66. Kumari, S.; Sarkar, P.K. Bacillus cereus hazard and control in industrial dairy processing environment. Food Control 2016, 69, 20-29. [CrossRef]

67. Pasvolsky, R.; Zakin, V.; Ostrova, I.; Shemesh, M. Butyric acid released during milk lipolysis triggers biofilm formation of Bacillus species. Int. J. Food Microbiol. 2014, 181, 19-27. [CrossRef]

68. Ostrov, I.; Sela, N.; Belausov, E.; Steinberg, D.; Shemesh, M. Adaptation of Bacillus species to dairy associated environment facilitates their biofilm forming ability. Food Microbiol. 2019, 82, 316-324. [CrossRef]

69. Doyle, C.J.; Gleeson, D.; Jordan, K.; Beresford, T.P.; Ross, R.; Fitzgerald, G.F.; Cotter, P.D. Anaerobic sporeformers and their significance with respect to milk and dairy products. Int. J. Food Microbiol. 2015, 197, 77-87. [CrossRef]

70. Odeyemi, O.A.; Alegbeleye, O.O.; Strateva, M.; Stratev, D. Understanding spoilage microbial community and spoilage mechanisms in foods of animal origin. Compr. Rev. Food Sci. Food Saf. 2020, 19, 311-331. [CrossRef]

71. Elariny, E.Y.T.; Ahmed, H.A.; Khatab, A.A.H.; Mohamed, R.E. Genotyping, Antibiotic Resistance and Biofilm Formation Ability of Clostridium perfringens Isolated from Raw Milk, Dairy Products and Human Consumers. J. Anim. Health Prod. 2021, 9, 34-41. [CrossRef]

72. Oh, S.; Chen, P.; Kang, D.-H. Biofilm Formation by Enterobacter Sakazakii Grown in Artificial Broth and Infant Milk Formula on Plastic Surface. J. Rapid Methods Autom. Microbiol. 2007, 15, 311-319. [CrossRef]

73. Gupta, T.B.; Mowat, E.; Brightwell, G.; Flint, S.H. Biofilm formation and genetic characterization of New Zealand Cronobacter isolates. J. Food Saf. 2018, 38, e12430. [CrossRef]

74. Colagiorgi, A.; Bruini, I.; Di Ciccio, P.A.; Zanardi, E.; Ghidini, S.; Ianieri, A. Listeria monocytogenes Biofilms in the Wonderland of Food Industry. Pathogens 2017, 6, 41. [CrossRef] [PubMed] 
75. Di Bonaventura, G.; Piccolomini, R.; Paludi, D.; D'Orio, V.; Vergara, A.; Conter, M.; Ianieri, A. Influence of temperature on biofilm formation by Listeria monocytogenes on various food-contact surfaces: Relationship with motility and cell surface hydrophobicity. J. Appl. Microbiol. 2008, 104, 1552-1561. [CrossRef]

76. Fagerlund, A.; Langsrud, S.; Møretrø, T. Microbial diversity and ecology of biofilms in food industry environments associated with Listeria monocytogenes persistence. Curr. Opin. Food Sci. 2021, 37, 171-178. [CrossRef]

77. Lianou, A.; Nychas, G.-J.; Koutsoumanis, K.P. Strain variability in biofilm formation: A food safety and quality perspective. Food Res. Int. 2020, 137, 109424. [CrossRef]

78. Lee, S.; Mangolin, B.; Gonçalves, J.L.; Neeff, D.; Silva, M.; da Cruz, A.G.; Oliveira, C. Biofilm-producing ability of Staphylococcus aureus isolates from Brazilian dairy farms. J. Dairy Sci. 2014, 97, 1812-1816. [CrossRef]

79. Thiran, E.; Di Ciccio, P.; Graber, H.; Zanardi, E.; Ianieri, A.; Hummerjohann, J. Biofilm formation of Staphylococcus aureus dairy isolates representing different genotypes. J. Dairy Sci. 2018, 101, 1000-1012. [CrossRef]

80. Avila-Novoa, M.-G.; Iñíguez-Moreno, M.; Solís-Velázquez, O.-A.; González-Gómez, J.-P.; Guerrero-Medina, P.-J.; Gutiérrez-Lomelí, M. Biofilm Formation by Staphylococcus aureus Isolated from Food Contact Surfaces in the Dairy Industry of Jalisco, Mexico. J. Food Qual. 2018, 2018, 1-8. [CrossRef]

81. Cody, S.H.; Abbott, S.L.; Marfin, A.A.; Schulz, B.; Wagner, P.; Robbins, K.; Mohle-Boetani, J.C.; Vugia, D.J. Two Outbreaks of Multidrug-Resistant Salmonella Serotype Typhimurium DT104 Infections Linked to Raw-Milk Cheese in Northern California. JAMA J. Am. Med. Assoc. 1999, 281, 1805-1810. [CrossRef] [PubMed]

82. Robinson, E.; Travanut, M.; Fabre, L.; Larréché, S.; Ramelli, L.; Pascal, L.; Guinard, A.; Vincent, N.; Calba, C.; Meurice, L.; et al. Outbreak of Salmonella Newport associated with internationally distributed raw goats' milk cheese, France. Epidemiol. Infect. 2020, 148, e180. [CrossRef] [PubMed]

83. Villar, R.G.; Macek, M.; Simons, S.; Hayes, P.S.; Goldoft, M.J.; Lewis, J.H.; Rowan, L.L.; Hursh, D.; Patnode, M.; Mead, P.S. Investigation of Multidrug-Resistant Salmonella Serotype Typhimurium DT104 Infections Linked to Raw-Milk Cheese in Washington State. JAMA J. Am. Med Assoc. 1999, 281, 1811-1816. [CrossRef]

84. Leyer, G.J.; Johnson, E.A. Acid adaptation promotes survival of Salmonella spp. in cheese. Appl. Environ. Microbiol. 1992, 58, 2075-2080. [CrossRef] [PubMed]

85. Van Kessel, J.A.S.; Karns, J.S.; Lombard, J.E.; Kopral, C.A. Prevalence of Salmonella enterica, Listeria monocytogenes, and Escherichia coli Virulence Factors in Bulk Tank Milk and In-Line Filters from U.S. Dairies. J. Food Prot. 2011, 74, 759-768. [CrossRef]

86. Lamas, A.; Regal, P.; Vázquez, B.; Miranda, J.M.; Cepeda, A.; Franco, C.M. Influence of milk, chicken residues and oxygen levels on biofilm formation on stainless steel, gene expression and small RNAs in Salmonella enterica. Food Control. 2018, 90, 1-9. [CrossRef]

87. Reitsma, C.J.; Henning, D.R. Survival of Enterohemorrhagic Escherichia coli O157:H7 During the Manufacture and Curing of Cheddar Cheese. J. Food Prot. 1996, 59, 460-464. [CrossRef] [PubMed]

88. Espié, E.; Vaillant, V.; Mariani-Kurkdjian, P.; Grimont, F.; Martin-Schaller, R.; De Valk, H.; Vernozy-Rozand, C. Escherichia coli O157 outbreak associated with fresh unpasteurized goats' cheese. Epidemiol. Infect. 2005, 134, 143-146. [CrossRef]

89. Honish, L.; Predy, G.; Hislop, N.; Chui, L.; Kowalewska-Grochowska, K.; Trottier, L.; Kreplin, C.; Zazulak, I. An Outbreak of E. coli O157:H7 Hemorrhagic Colitis Associated with Unpasteurized Gouda Cheese. Can. J. Public Health 2005, 96, 182-184. [CrossRef]

90. Spano, G.; Goffredo, E.; Beneduce, L.; Tarantino, D.; Dupuy, A.; Massa, S. Fate of Escherichia coli O157:H7 during the manufacture of Mozzarella cheese. Lett. Appl. Microbiol. 2003, 36, 73-76. [CrossRef]

91. Sharma, M.; Anand, S. Characterization of constitutive microflora of biofilms in dairy processing lines. Food Microbiol. 2002, 19, 627-636. [CrossRef]

92. Aryal, M.; Muriana, P.M. Efficacy of Commercial Sanitizers Used in Food Processing Facilities for Inactivation of Listeria monocytogenes, E. Coli O157:H7, and Salmonella Biofilms. Foods 2019, 8, 639. [CrossRef] [PubMed]

93. Wang, R.; Bono, J.L.; Kalchayanand, N.; Shackelford, S.; Harhay, D.M. Biofilm Formation by Shiga Toxin-Producing Escherichia coli O157:H7 and Non-O157 Strains and Their Tolerance to Sanitizers Commonly Used in the Food Processing Environment. J. Food Prot. 2012, 75, 1418-1428. [CrossRef]

94. Greene, A.K.; Few, B.K.; Serafini, J.C. A Comparison of Ozonation and Chlorination for the Disinfection of Stainless Steel Surfaces. J. Dairy Sci. 1993, 76, 3617-3620. [CrossRef]

95. Dosti, B.; Guzel-Seydim, Z.; Greene, A.K. Effectiveness of ozone, heat and chlorine for destroying common food spoilage bacteria in synthetic media and biofilms. Int. J. Dairy Technol. 2005, 58, 19-24. [CrossRef]

96. Shelobolina, E.S.; Walker, D.K.; Parker, A.E.; Lust, D.V.; Schultz, J.M.; Dickerman, G.E. Inactivation of Pseudomonas aeruginosa biofilms formed under high shear stress on various hydrophilic and hydrophobic surfaces by a continuous flow of ozonated water. Biofouling 2018, 34, 826-834. [CrossRef] [PubMed]

97. Tachikawa, M.; Yamanaka, K. Synergistic disinfection and removal of biofilms by a sequential two-step treatment with ozone followed by hydrogen peroxide. Water Res. 2014, 64, 94-101. [CrossRef] [PubMed]

98. Harada, A.M.M.; Nascimento, M.S. Effect of dry sanitizing methods on Bacillus cereus biofilm. Braz. J. Microbiol. 2021, 52, 919-926. [CrossRef]

99. Babu, K.S.; Liu, Z.; Amamcharla, J.K. 0713 Use of fluorescence-based Amaltheys analyzer for studying effect of pH and heat on whey protein interactions in reconstituted milk protein concentrate. J. Anim. Sci. 2016, 94, 341-342. [CrossRef] 
100. Tiwari, M.; Scannell, A.; O' Donnell, C. Effect of ozone in combination with cleaning in place reagent (cip) to control biofilms of spore-formers in food process environment. In Biosystems and Food Engineering Research Review 22; Cummins, E.J., Curran, T.P., Eds.; University College Dublin: Dublin, Ireland, 2017.

101. Korany, A.M.; Hua, Z.; Green, T.; Hanrahan, I.; El-Shinawy, S.H.; El-Kholy, A.; Hassan, G.; Zhu, M.-J. Efficacy of Ozonated Water, Chlorine, Chlorine Dioxide, Quaternary Ammonium Compounds and Peroxyacetic Acid Against Listeria monocytogenes Biofilm on Polystyrene Surfaces. Front. Microbiol. 2018, 9, 2296. [CrossRef]

102. Robbins, J.B.; Fisher, C.W.; Moltz, A.G.; Martin, S.E. Elimination of Listeria monocytogenes Biofilms by Ozone, Chlorine, and Hydrogen Peroxide. J. Food Prot. 2005, 68, 494-498. [CrossRef] [PubMed]

103. Nicholas, R.; Dunton, P.; Tatham, A.; Fielding, L. The effect of ozone and open air factor on surface-attached and biofilm environmental Listeria monocytogenes. J. Appl. Microbiol. 2013, 115, 555-564. [CrossRef] [PubMed]

104. Harada, A.M.; Nascimento, M.S. Efficacy of dry sanitizing methods on Listeria monocytogenes biofilms. Food Control. 2021, 124, 107897. [CrossRef]

105. Baumann, A.R.; Martin, S.E.; Feng, H. Removal of Listeria monocytogenes Biofilms from Stainless Steel by Use of Ultrasound and Ozone. J. Food Prot. 2009, 72, 1306-1309. [CrossRef] [PubMed]

106. Cabo, M.; Herrera, J.; Crespo, M.; Pastoriza, L. Comparison among the effectiveness of ozone, nisin and benzalkonium chloride for the elimination of planktonic cells and biofilms of Staphylococcus aureus CECT4459 on polypropylene. Food Control 2009, 20, 521-525. [CrossRef]

107. Shao, L.; Dong, Y.; Chen, X.; Xu, X.; Wang, H. Modeling the elimination of mature biofilms formed by Staphylococcus aureus and Salmonella spp. Using combined ultrasound and disinfectants. Ultrason. Sonochem. 2020, 69, 105269. [CrossRef]

108. Silva, V.; Peirone, C.; Amaral, J.S.; Capita, R.; Alonso-Calleja, C.; Marques-Magallanes, J.A.; Martins, Â.; Carvalho, Á.; Maltez, L.; Pereira, J.E.; et al. High Efficacy of Ozonated Oils on the Removal of Biofilms Produced by Methicillin-Resistant Staphylococcus aureus (MRSA) from Infected Diabetic Foot Ulcers. Molecules 2020, 25, 3601. [CrossRef]

109. Singla, R.; Goel, H.; Ganguli, A. Novel synergistic approach to exploit the bactericidal efficacy of commercial disinfectants on the biofilms of Salmonella enterica serovar Typhimurium. J. Biosci. Bioeng. 2014, 118, 34-40. [CrossRef]

110. Commission Regulation (EC) No. 2073/2005. Microbiological Criteria for Foodstuffs. 2005. Available online: https://eur-lex. europa.eu/legal-content/EN/TXT/?uri=CELEX\%3A02005R2073-20200308\&qid=1641987351211 (accessed on 1 December 2021).

111. Foegeding, P. Ozone inactivation of Bacillus and Clostridium spore populations and the importance of the spore coat to resistance. Food Microbiol. 1985, 2, 123-134. [CrossRef]

112. Novak, J.S.; Yuan, J.T.C. Increased Inactivation of Ozone-Treated Clostridium perfringens Vegetative Cells and Spores on Fabricated Beef Surfaces Using Mild Heat. J. Food Prot. 2004, 67, 342-346. [CrossRef]

113. Torlak, E.; Sert, D. Inactivation of Cronobacter by gaseous ozone in milk powders with different fat contents. Int. Dairy J. 2013, 32, 121-125. [CrossRef]

114. Ölmez, H.; Temur, S. Effects of different sanitizing treatments on biofilms and attachment of Escherichia coli and Listeria monocytogenes on green leaf lettuce. LWT 2010, 43, 964-970. [CrossRef]

115. Souza, S.M.D.O.; De Alencar, E.R.; Ribeiro, J.L.; Ferreira, M.D.A. Inactivation of Escherichia coli O157:H7 by ozone in different substrates. Braz. J. Microbiol. 2019, 50, 247-253. [CrossRef] [PubMed]

116. Mohammad, Z.; Kalbasi-Ashtari, A.; Riskowski, G.; Castillo, A. Reduction of Salmonella and Shiga toxin-producing Escherichia coli on alfalfa seeds and sprouts using an ozone generating system. Int. J. Food Microbiol. 2019, 289, 57-63. [CrossRef] [PubMed] 